\title{
Laboratory simulation of dissolved oxygen reduction and ammonia nitrogen generation in the decay stage of harmful algae bloom*
}

\author{
Qiaoning WANG ${ }^{1,5,6, \#}$, Xiaodong $\mathrm{LI}^{1,4, \#}{ }^{1}$, Tian $\mathrm{YAN}^{1,2,3, * *}$, Jingjing SONG ${ }^{1}$, \\ Rencheng $\mathrm{YU}^{1,2,3}$, Mingjiang ZHOU ${ }^{1}$ \\ ${ }^{1}$ Key Laboratory of Marine Ecology and Environmental Sciences, Institute of Oceanology, Chinese Academy of Sciences, \\ Qingdao 266071, China \\ ${ }^{2}$ Laboratory of Marine Ecology and Environmental Science, Qingdao National Laboratory for Marine Science and Technology, \\ Qingdao 266071, China \\ ${ }^{3}$ Centre for Ocean Mega-Science, Chinese Academy of Sciences, Qingdao 266071, China \\ ${ }^{4}$ Key Laboratory of Marine Biotechnology of Fujian Province, Institute of Oceanology, College of Animal Sciences, Fujian \\ Agriculture and Forestry University, Fuzhou 350002, China \\ ${ }^{5}$ CAS Key Laboratory of Coastal Environmental Processes and Ecological Remediation, Yantai Institute of Coastal Zone \\ Research, Chinese Academy of Sciences, Yantai 264003, China \\ ${ }^{6}$ University of Chinese Academy of Sciences, Beijing 100049, China
}

Received Nov. 12, 2019; accepted in principle Jan. 7, 2020; accepted for publication Feb. 19, 2020

(C) Chinese Society for Oceanology and Limnology, Science Press and Springer-Verlag GmbH Germany, part of Springer Nature 2021

Abstract To evaluate how the decay of bloom-forming algae affect the coastal dissolved oxygen, a laboratory simulation was conducted in terms of three typical harmful algae, Alexandrium catenella, Prorocentrum donghaiense, and Skeletonema costatum. Algae of same biomass $(55 \mu \mathrm{g} / \mathrm{mL})$ were conducted in lightproof columns, and the cell density, dissolved oxygen (DO), and ammonia nitrogen of different layers were monitored at certain time series. Results show that the decomposition of algae significantly decreased the DO, and increased the ammonia nitrogen in all layers; and significant deference between different species was observed. The $A$. catenella treatment showed the lowest DO (average concentration of $3.4 \mathrm{mg} / \mathrm{L}$ ) and the highest ammonia nitrogen (average concentration of $0.98 \mathrm{mg} / \mathrm{L}$ ) at the end of test, followed by $P$. donghaiense; and the $S$. costatum showed relatively high DO and low ammonia nitrogen due to slow decay rate. Results indicate that decomposition of harmful bloom algae, especially dinoflagellate, would cause significantly DO depletion and toxic ammonia nitrogen increase, which will detrimentally affect both pelagic and benthic ecosystem.

Keyword: harmful algal bloom; hypoxia; Alexandrium catenella; Prorocentrum donghaiense; Skeletonema costatum

\section{INTRODUCTION}

Marine eutrophication, especially the coastal and estuarine eutrophication, which is highly related with human activities (Micheli, 1999; Howarth and Marino, 2006; Jessen et al., 2015), resulted in frequent harmful algal blooms (HABs) and marine dissolved oxygen reduction (Glibert and Pitcher, 2001; Karlson et al., 2002; Small et al., 2014; Chan et al., 2019), and caused huge ecosystem destruction and massive mortality of aquaculture species (Morrison et al.,
* Supported by the Strategic Priority Research Program of the Chinese Academy of Sciences (No. XDA23050302), the Marine S\&T Fund of Shandong Province for Pilot National Laboratory for Marine Science and Technology (Qingdao) (No. 2018SDKJ050404), the Science \& Technology Basic Resources Investigation Program of China (No. 2018FY100200), the Sino-Australian Centre for Healthy Coasts (No. 2016YFE0101500), the Key Deployment Project of Centre for Ocean Mega-Research of Science, Chinese Academy of Science (No. COMS2019Q05), and the NSFC (Nos. 41476102, U1406403)

** Corresponding author: tianyan@qdio.ac.cn

\# Qiaoning WANG and Xiaodong LI contributed equally to this work and should be regarded as co-first authors. 
1991; Reise and van Beusekom, 2008; Li et al., 2017). Occurrence of hypoxia and anoxia zone (dissolved oxygen $(\mathrm{DO})<2 \mathrm{mg} / \mathrm{L}$ or $=0 \mathrm{mg} / \mathrm{L}$ ) could have detrimental impacts on both pelagic and benthic organism (Diaz and Rosenberg, 1995; Marcus, 2001; Vaquer-Sunyer and Duarte, 2008). It was suggested that both the benthic community structure (biomass, diversity, density, distribution, organism size, and function, etc.) and process (rates and depth of bioturbation, biochemical zonation, and productivity, etc.) were significantly affected by marine hypoxia (Hartmann et al., 2009; Shivarudrappa et al., 2009, 2019; Riedel et al., 2016; Fajardo et al., 2018; Yang et al., 2019), as well as those of pelagic community (Ekau et al., 2010; Kimmel et al., 2010; Elliott et al., 2013; Lučić et al., 2019). Survival rate, behaviour, reproduction of valuable culture species (fish and shellfish) and eco-key species (copepods) were also inhibited by hypoxia or moderate hypoxia (Stalder and Marcus, 1997; Lai et al., 2016; Gu et al., 2019; Samuel et al., 2019).

In addition to that the occurrence of hypoxia and anoxia zone were related with hydrodynamic factors, such as terrain, tide, and current (Luo et al., 2005; Shi et al., 2005), previous observation also suggested the HABs and marine dissolved oxygen reduction were also highly related (Glibert and Pitcher, 2001; Gentien et al., 2003). Morrison et al. (1991) reported a significant oxygen reduction of $2.0 \pm 0.3 \mathrm{mg} / \mathrm{L}$ after a diatom (Skeletonema costatum) bloom in Firth of Clyde, Scotland, which caused massive mortality of herring (Clupea harengus) eggs. Trainer et al. (2010) analyzed the impact of HABs on a typical upwelling coastal system, and suggested that large scale HABs could obviously reduce the DO level of upwelling coast. O'Boyle et al. (2016) suggested a significant liner relationship between dinoflagellate Karenia mikimotoi density and coastal DO concentration, using both field modelling and laboratory simulation. However, direct evidence of DO reduction caused by HABs species is still lacking, and laboratory simulation of this process on different species is needed.

Coastal regions of China were recognized as the main affected region of both HABs and marine dissolved oxygen reduction. Hypoxia were observed almost everywhere throughout Chinese coastal regions (Wang et al., 2012a; He et al., 2014; Li et al., 2014; Zhang et al., 2016; Zhao et al., 2017), and annual hypoxia was reported in the Changjiang (Yangtze) River estuary, with a stunning coverage over $12000 \mathrm{~km}^{2}$ (Chen et al., 2007a; Wei et al., 2007; Li et al., 2011; Zheng et al., 2016). Large scale HABs, with bloom species including dinoflagellate and diatom, were frequently reported in this region. For example, blooms of the paralytic shellfish poisoning producer Alexandrium catenella covered an area of $1000 \mathrm{~km}^{2}$ near Zhoushan coast of Zhejiang Province in 2006. Prorocentrum donghaiense bloomed over 155 times during 2000-2009, with cumulative area over $6.7 \times 10^{4} \mathrm{~km}^{2}$; and the diatom $S$. costatum annually blooms in this area (Liang, 2012). Their bloom area were highly consisted with the low oxygen region (Luo et al., 2005; Shi et al., 2005; Yu et al., 2018). Results of sediment analyses also indicated that the bottom oxygen lack in the Changjiang River estuary was related to massive biomass sedimentation of bloom algae (Guo, 2013; Kang et al., 2016). To explore the relationship of HABs and DO reduction, three typical bloom-forming species, A. catenella, $P$. donghaiense, and S. costatum, were selected; and the DO concentration changes, as well as the changes of algal density and ammonia nitrogen, were simulated and measured during algal decay in laboratory condition.

\section{MATERIAL AND METHOD}

The algae strains of $A$. catenella, $P$. donghaiense, $S$. costatum were provided by the Algal Culture Centre of the Institute of Oceanology, Chinese Academy of Sciences (IOCAS), and cultured in $\mathrm{f} / 2$ seawater medium (Guillard and Ryther, 1962) at temperature $20 \pm 1{ }^{\circ} \mathrm{C}, \mathrm{pH} \quad 8.09 \pm 0.05$, and salinity $30 \pm 1$ under a $12 \mathrm{~h}: 12 \mathrm{~h}$ photoperiod using cool-white fluorescent lamps $(2650 \pm 1001 \mathrm{~lx})$. Culture cell numbers were counted by haemocytometer under a microscope. Seawater piped from Huiquan Bay, Qingdao, China $\left(36^{\circ} 02^{\prime} 57.61^{\prime \prime} \mathrm{N}, 120^{\circ} 20^{\prime} 118^{\prime \prime} \mathrm{E}\right)$ were filtered through sand and $0.45-\mu \mathrm{m}$ filter (Xinya, Shanghai, China), and autoclaved for $25 \mathrm{~min}$ at $121{ }^{\circ} \mathrm{C}$ before use.

Test was conducted in a one end closed, light-proof plexiglass tube $(\varphi=8 \mathrm{~cm}$, length $=3 \mathrm{~m})$ with 15 -L algal culture of A. catenella, P. donghaiense, S. costatum, respectively. Final densities of each algal were $0.74 \times 10^{4}, \quad 7.9 \times 10^{4}, \quad$ and $27.5 \times 10^{4}$ cells $/ \mathrm{mL}$, respectively, which biomass were same at the bloom biomass of $55 \mu \mathrm{g} / \mathrm{mL}$ (dry weight, from unpublished data of Dr. SONG J. J. from IOCAS). Each algal treatment was conducted in triplicate at temperature $20 \pm 1{ }^{\circ} \mathrm{C}$. Samples $(5 \mathrm{~mL} \times 3)$ were taken from $30 \mathrm{~cm}$ (surface), $150 \mathrm{~cm}$ (middle), and $300 \mathrm{~cm}$ (bottom) at 0 , 

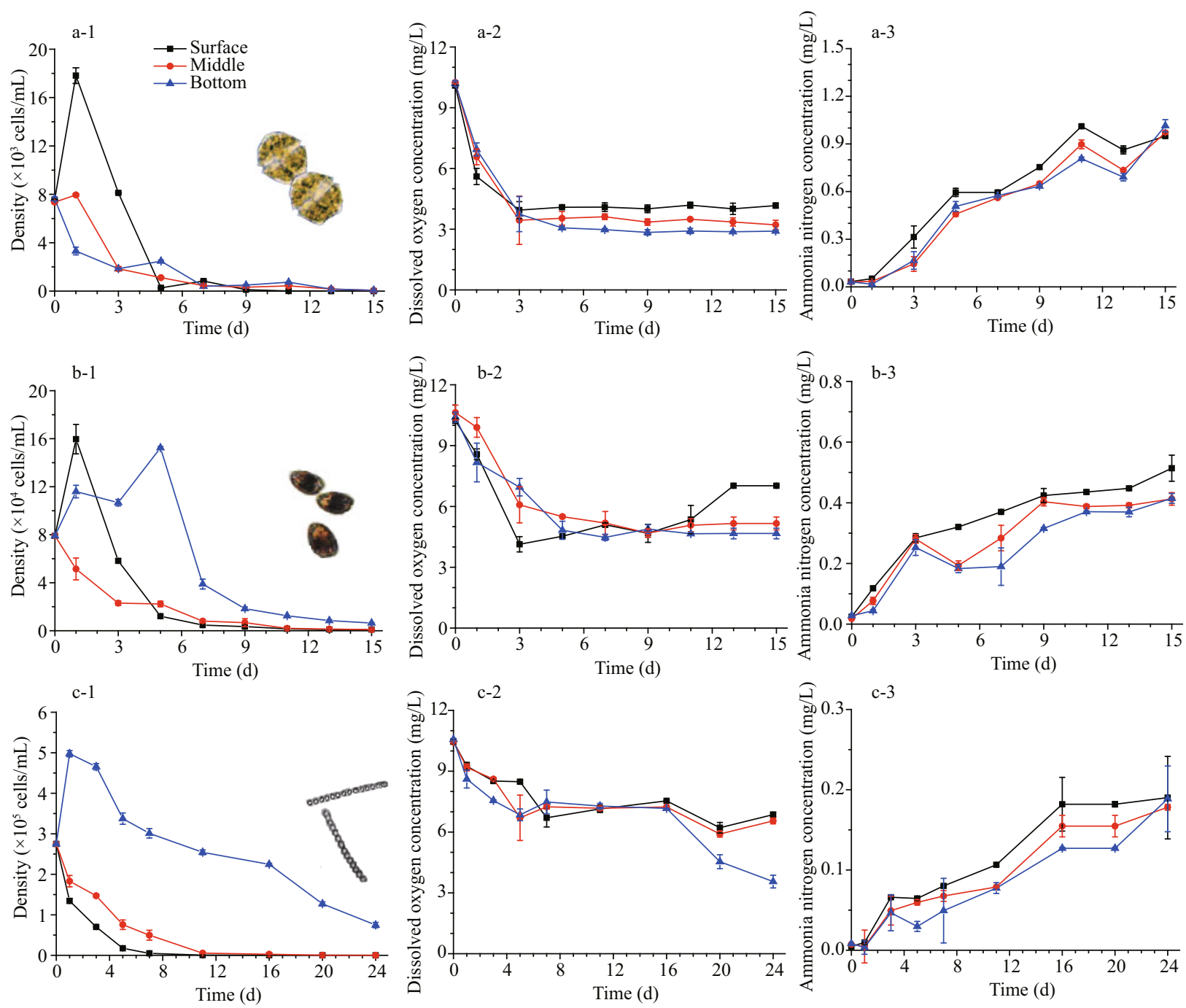

Fig.1 Changes of hypoxia related parameters in different algal treatments

The letters ( $\mathrm{a}, \mathrm{b}, \mathrm{c})$ represented algal treatments of Alexandrium catenella, Prorocentrum donghaiense, Skeletonema costatum; numbers (1, 2, 3) represented the cell density, dissolved oxygen, and ammonia nitrogen in each treatment, and lines with different color and dot represent water lays. Dots indicate the mean of triplicate measurements; the bars indicate standard deviation. Algae pictures (Lu et al., 2005; Chen et al., 2007b; Chang, 2015) are listed for better understanding.

$1,3,5,7,9,11,13$, and $15 \mathrm{~d}$ for A. catenella, P. donghaiense, and 0, 1, 3, 5, 7, 9, 11, 16, 20, and $24 \mathrm{~d}$ for $S$. costatum. Iodometry was used to measure the dissolved oxygen, and indophenol blue photometric method were used to measure the ammoniacal nitrogen, as recommend in National specification for marine monitoring of China (GB17378.4-2007) (General Administration of Quality Supervision, Inspection and Quarantine of the People's Republic of China and Standardization Administration of China, 2007). Experimental data were analyzed by one-way analysis of variance (ANOVA) with the Statistical Package for the Social Sciences (SPSS) version 19.0 (SPSS, Inc., Chicago, IL, USA). Sample differences were considered to be statistically significant at $P<0.05$.

\section{RESULT}

During the long-term incubation in dark condition, the density of all three test algae were significantly decreased $(P<0.05)$ in surface, middle and bottom layer of the column (Fig.1). However, different algal showed different vertical migration during the incubation. Dinoflagellate showed significant surface gathering $(P<0.05)$ at day one, especially A. catenella, whose density in bottom decreased to $3300 \pm$ 320 cells $/ \mathrm{mL}$, which is only $18.6 \%$ of that in surface (Fig.1a-1). The cells of $P$. donghaiense migrated to both surface and bottom, with pick density of $(15.9 \pm 1.2) \times 10^{4}$ cells $/ \mathrm{mL} \quad(1 \mathrm{~d})$ and $(15.2 \pm 1.2) \times$ $10^{4}$ cells $/ \mathrm{mL}(5 \mathrm{~d})$, respectively, while the density in middle layer significantly decreased (Fig.1b-1). 
Table 1 Correlation among algae density, dissolved oxygen (DO), and ammonia nitrogen (AN) of each layer in three algae treatments

\begin{tabular}{clccc}
\hline Species & Layer & Density vs DO & Density vs AN & DO vs AN \\
\hline \multirow{2}{*}{$\begin{array}{c}\text { Alexandrium } \\
\text { catenella }\end{array}$} & Surface & 0.427 & -0.847 & -0.671 \\
& Middle & 0.891 & -0.831 & -0.695 \\
& Bottom & 0.948 & -0.776 & -0.769 \\
\cline { 2 - 5 } & Surface & 0.570 & -0.829 & -0.614 \\
Prorocentrum & Middle & 0.960 & -0.949 & -0.909 \\
donghaiense & Bottom & 0.458 & -0.709 & -0.788 \\
\cline { 2 - 5 } & Surface & 0.896 & -0.747 & -0.810 \\
Skeletonema & Middle & 0.940 & -0.846 & -0.828 \\
& Bostatum & 0.656 & -0.830 & -0.926 \\
\hline
\end{tabular}

However, the cells of diatom $S$. costatum immediately sank to bottom of the column, and slowly decayed (Fig.1c-1). After 24-d incubation, the cell density of $S$. costatum in the bottom still maintained at $(0.75 \pm 0.07) \times 10^{5}$ cells $/ \mathrm{mL}$ (about $27.2 \%$ of bottom density at $0 \mathrm{~d}$ ), while densities of $A$. catenella and $P$. donghaiense at each layer dropped to nearly 0 in fifteen days.

The DO concentration also showed significant decrease $(P<0.05)$ in all three layers, and slight difference was observed between different algae (Fig.1). DO concentrations of three testing layers of A. catenella treatment significantly dropped $(P<0.05)$ to below $4 \mathrm{mg} / \mathrm{L}$ within three days, and maintained at about 4.1,3.4, and $2.9 \mathrm{mg} / \mathrm{L}$ (surface to bottom) in the following days with little fluctuation (Fig.1a-2). The DO concentration in $P$. donghaiense treatment also declined rapidly, especially that in the surface, which dropped from $10.2 \pm 0.12 \mathrm{mg} / \mathrm{L}$ to $4.1 \pm 0.38 \mathrm{mg} / \mathrm{L}$ in three days. However, the surface DO increased to $7.0 \pm 0.04 \mathrm{mg} / \mathrm{L}$ in $13 \mathrm{~d}$, while middle and bottom DO slowly decreased to about $5.0 \mathrm{mg} / \mathrm{L}$ on Day 9 , and stayed with little fluctuation until the end (Fig.1b-2). The DO concentration of $S$. costatum treatment also declined, but the surface and middle layers DO remain above $5.0 \mathrm{mg} / \mathrm{mL}$ in the entire tests, which were significantly higher $(P<0.05)$ than that in the A. catenella treatment. However, the bottom DO dropped rapidly after Day 16, and it was tested as $3.6 \pm 0.31 \mathrm{mg} / \mathrm{L}$ on Day 24 , which was significantly lower $(P<0.05)$ than that in middle and surface layers of same treatment.

The ammonia nitrogen significantly increased $(P<0.05)$ in all test layer and treatment. In each algae treatment, the difference of ammonia nitrogen concentration between layers was not significant
$(P>0.05)$, but for different algae treatment, their increasing degree were quite different $(P<0.05)$. The averaged ammonia nitrogen in $A$. catenella treatment was tested as $0.98 \pm 0.049 \mathrm{mg} / \mathrm{L}$ on Day 15 , which was about 5.3 times of that in $S$. costatum treatment on Day 24 and 2.2 times of that in P. donghaiense treatment on Day 15.

As shown in Table 1, the algae density was positively correlated with $\mathrm{DO}$, and negatively correlated with ammonia nitrogen, while the DO was negatively correlated with ammonia nitrogen. It also showed that the correlation of those three parameters varied with algae species and layers. In A. catenella treatment, the algae density was strongly correlated with DO in both middle and bottom, while in $P$. donghaiense treatment, all three parameters were more closely correlated in the middle than other layers. The relation between DO and ammonia nitrogen were lower in most algae treatments and layers; however, they were strongly related in bottom layers of $S$. costatum treatment.

\section{DISCUSSION}

An interesting phenomenon of cell mobility was observed in this test, and obvious different motility modes for three test algae were detected. Dinoflagellates were aggregated to surface layer on Day 1, even in the dark condition, which indicated an inner rhythm of vertical migration. It was suggested that the migration of A. catenella was the most obvious among the three test species, with surface density over double of middle density and five times of bottom density in $1 \mathrm{~d}$ (Fig.1a-1). The structural analysis of flagellar suggested that the $A$. catenella had strong movement ability (Hansen and Moestrup, 1998). Lewis et al. (2006) suggested speeds of 30$470 \mu \mathrm{m} / \mathrm{s}$ for other Alexandrium species. However, the exact swimming speed of $A$. catenella was still unclear. $P$. donghaiense also have flagellum, and surface accumulation was observed on Day 1 (Fig.1b-1), but in contrary to A. catenella, the bottom densities were also increased in six days, suggesting a different migration mechanism. The diatom S. costatum has no movement ability, and significant descent was observed (Fig.1c-1). However, the decay of $S$. costatum was significantly slower than dinoflagellate. It may be related with the siliceous shell to keep the algal cells intact, which also related to its slow DO consumption.

Results also suggest that the DO reduction was related with the decay speed of algal cells. With 
biomass (dry weight) set at $55 \mu \mathrm{g} / \mathrm{mL}$ samely for each treatment, the reduction speed and degree varied with species. The decay speed of $A$. catenella was faster than other species, and its DO reduction speed was faster and degree was deeper than that of other treatment. The DO of $A$. catenella treatment was stable on a low level within 5 days, exactly when the heavily cells density declines happened. The decomposing of $S$. costatum was the slowest, so that the DO reduction speed was the slowest and the degree was the slightest among the three treatments. Results also indicate that DO reduction was partly related to the cells distribution, especially in the middle layer (Table 1). On Days 16-24, the decomposing of $S$. costatum caused the significant DO decline in the bottom (Fig.1c-1 \& c-2). Moreover, the DO concretion may be influenced by other factors, such as surface exchange, making DO concentrations decline with water depth.

Ammonia nitrogen increase was noticed. Decomposing of massive algae, in both micro and macro level, would generate huge amount of ammonia nitrogen (Branch et al., 2013; Wang et al., 2012b). Significant difference was observed between algae treatments. The final concentration (on Day 15) of ammonia nitrogen in A. catenella treatment was the highest among the three treatments, which might be caused by the high nitrogen content itself. The ammonia nitrogen concentrations of the three algae were highly consistent with the nitrogen content of algal cells (unpublished data). Ammonia nitrogen was very lethal to marine fauna, especially to their larva or juvenile. Reddy-Lopata et al. (2006) suggested that survival of the juvenile abalone Haliotis midae (length $1-2 \mathrm{~cm}$ ) was significantly inhibited by ammonia nitrogen at concentration of $7.4 \mu \mathrm{g} / \mathrm{L}$, which was much lower than ammonia nitrogen released by algae in this article. Lethal or other adverse effect also reported for clam (Wang et al., 2007; Chen et al., 2010), amphipods (Kohn et al., 1994), and fish (Zhu et al., 2018).

The results provide direct evidence that decay of harmful species could cause DO reduction and ammonia nitrogen increase in a still water, which was considered as a reflection of real coastal environment. All the tested algae in this research frequently bloomed along coasts of China, especially $P$. donghaiense and S. costatum, with hundreds bloom cases reported, in vast bloom area and high algal density (Liang, 2012). In the Changjiang River estuary, density of annual bloom of $P$. donghaiense were over $10^{5}$ cells $/ \mathrm{mL}$ (Yu et al., 2018), suggesting that the DO might be lower than $4 \mathrm{mg} / \mathrm{L}$ in several days with increased ammonia nitrogen according to our results. This may cause detrimental impacts to both pelagic and benthic organism, and further lead to a great damage to the coastal ecosystem.

\section{CONCLUSION}

The laboratory simulation has proved that the decay of harmful algae could significantly decrease the DO in the water column, and the results show that the ammonia nitrogen increased with simulation time. However, the degree of DO consumption and ammonia nitrogen production varied with algal species, with the degree order (strong to weak) as A. catenella, $P$. donghaiense, and S. costatum, which could be explained by difference in decay rate and elementary composition between species. The decay of massive HABs, especially dinoflagellate blooms, could cause significant DO consumption and toxic ammonia nitrogen increase, which have a detrimental impact on both pelagic and benthic ecosystems.

\section{DATA AVAILABILITY STATEMENT}

The datasets generated and/or analyzed during the current study are available from the corresponding author on reasonable request.

\section{ACKNOWLEDGMENT}

We thank the anonymous reviewers for valuable comments and the editors for manuscript polishing towards the improvement of this paper.

\section{References}

Branch G M, Bustamante R H, Robinson T B. 2013. Impacts of a 'black tide' harmful algal bloom on rocky-shore intertidal communities on the West Coast of South Africa. Harmful Algae, 24: 54-64, https://doi.org/10.1016/j. hal.2013.01.005

Chan F, Barth J A, Kroeker K Lubchenco J, Menge B A. 2019. The dynamics and impact of ocean acidification and hypoxia: insights from sustained investigations in the Northern California current large marine ecosystem. Oceanography, 32(3): 62-71, https://doi.org/10.5670/ oceanog.2019.312.

Chang F H. 2015. Cytotoxic effects of Vicicitus globosus (class dictyochophyceae) and Chattonella marina (class raphidophyceae) on rotifers and other microalgae. Journal of Marine Science and Engineering, 3(2): 401-411, https://doi.org/10.3390/jmse3020401.

Chen C C, Gong G C, Shiah F K. 2007a. Hypoxia in the East 
China Sea: one of the largest coastal low-oxygen areas in the world. Marine Environmental Research, 64(4): 399408, https://doi.org/10.1016/j.marenvres.2007.01.007.

Chen G F, Wang G C, Zhang B Y, Fan X L. 2007b. Morphological and phylogenetic analysis of Skeletonema costatum-like diatoms (Bacillariophyta) from the China Sea. European Journal of Phycology, 42(2): 163-175, https://doi.org/10.1080/09670260601149784.

Chen J, Hu Y X, Xu F R, Jin J Y. 2010. Acute toxicity experiments of ammonia-N and sulfide to the juveniles and adults of Meretrix meretrix. Modern Agricultural Sciences and Technology, (3): 324-325, 331, https://doi. org/10.3969/j.issn.1007-5739.2010.03.223. (in Chinese with English abstract)

Diaz R J, Rosenberg R. 1995. Marine benthic hypoxia: a review of its ecological effects and the behavioural responses of benthic macrofauna. Oceanography and Marine Biology: An Annual Review, 33: 245-303.

Ekau W, Auel H, Pörtner H O, Gilbert D. 2010. Impacts of hypoxia on the structure and processes in pelagic communities (zooplankton, macro-invertebrates and fish). Biogeosciences, 7(5): 1 669-1 699, https://doi.org/10. 5194/bg-7-1669-2010.

Elliott D T, Pierson J J, Roman M R. 2013. Copepods and hypoxia in Chesapeake Bay: abundance, vertical position and non-predatory mortality. Journal of Plankton Research, 35(5): 1 027-1 034, https://doi.org/10.1093/ plankt/fbt049.

Fajardo M, Andrade D, Bonicelli J, Bon M, Gómez G, Riascos J M, Pacheco A S. 2018. Macrobenthic communities in a shallow normoxia to hypoxia gradient in the Humboldt upwelling ecosystem. PLoS One, 13(7): e0200349, https://doi.org/10.1371/journal.pone.0200349.

General Administration of Quality Supervision, Inspection and Quarantine of the People's Republic of China, Standardization Administration of China. 2008. The specification for marine monitoring-Part 4: seawater analysis (GB 17378.4-2007). Standards Press of China. (in Chinese)

Gentien P, Pitcher G, Cembella A, Glibert P. 2003. Global Ecology and Oceanography of Harmful Algal Blooms: Implementation Plan. SCOR, IOC, Baltimore.

Glibert P M, Pitcher G. 2001. Global Ecology and Oceanography of Harmful Algal Blooms: Science Plan: An International Programme Sponsored by the Scientific Committee on Oceanic Research (SCOR) and the Intergovernmental Oceanographic Commission (UNESCO). SCOR, IOC, Baltimore. 86p.

Gu H X, Shang Y Y, Clements J, Dupont S, Wang T, Wei S S, Wang X H, Chen J F, Huang W, Hu M H, Wang Y J. 2019. Hypoxia aggravates the effects of ocean acidification on the physiological energetics of the blue mussel Mytilus edulis. Marine Pollution Bulletin, 149: 110538, https:// doi.org/10.1016/j.marpolbul.2019.110538.

Guillard R R L, Ryther J H. 1962. Studies of marine planktonic diatoms: I. Cyclotella Nana Hustedt, and Detonula Confervacea (Cleve) Gran. Canadian Journal of
Microbiology, 8(2): 229-239, https://doi.org/10.1139/ m62-029.

Guo W. 2013. Sedimentary Records of Hypoxia Status in the Red-Tide Zone of the East China Sea. Institute of Oceanology, Chinese Academy of Sciences, Qingdao. (in Chinese)

Hansen G, Moestrup Ø. 1998. Fine-structural characterization of Alexandrium catenella (Dinophyceae) with special emphasis on the flagellar apparatus. European Journal of Phycology, 33(4): 281-291, https://doi.org/10. 1080/09670269810001736783.

Hartmann V A, Briggs K, Shivarudrappa S, Yeager K M, Diaz R. 2009. The impact of hypoxia on bioturbation rates in the Louisiana continental shelf, Northern Gulf of Mexico. In: Proceedings of OCEANS 2009. IEEE, Biloxi, USA. p.1-9, https://doi.org/10.23919/OCEANS.2009.5422171.

He B Y, Dai M H, Zhai W D, Guo X H, Wang L F. 2014. Hypoxia in the upper reaches of the Pearl River Estuary and its maintenance mechanisms: a synthesis based on multiple year observations during 2000-2008. Marine Chemistry, 167: 13-24, https://doi.org/10.1016/j. marchem.2014.07.003.

Howarth R W, Marino R. 2006. Nitrogen as the limiting nutrient for eutrophication in coastal marine ecosystems: Evolving views over three decades. Limnology and Oceanography, 51(1): 364-376, https://doi.org/10.4319/ 10.2006.51.1_part_2.0364.

Jessen C, Bednarz V N, Rix L Teichberg M, Wild C. 2015. Marine eutrophication. In: Armon R H, Hänninen O eds. Environmental Indicators. Springer, Dordrecht. p.177203, https://doi.org/10.1007/978-94-017-9499-2_11.

Kang Z J, Yu R C, Kong F Z, Wang Y F, Gao Y, Chen J H, Guo W, Zhou M J. 2016. Records of bulk organic matter and plant pigments in sediment of the "red-tide zone" adjacent to the Changjiang River estuary. Chinese Journal of Oceanology and Limnology, 34(5): 915-927, https://doi. org/10.1007/s00343-016-4313-0.

Karlson K, Rosenberg R, Bonsdorff E. 2002. Temporal and spatial large-scale effects of eutrophication and oxygen deficiency on benthic fauna in Scandinavian and Baltic waters - a review. Oceanography and Marine Biology: An Annual Review, Aberdeen University Press/Allen \& Unwin, 40: 427-489.

Kimmel D G, Boicourt W C, Pierson J J, Roman M R, Zhang X S. 2010. The vertical distribution and diel variability of mesozooplankton biomass, abundance and size in response to hypoxia in the northern Gulf of Mexico USA. Journal of Plankton Research, 32(8): 1 185-1 202, https:// doi.org/10.1093/plankt/fbp136.

Kohn N P, Word J Q, Niyogi D K, Dillon T, Moore D W. 1994. Acute toxicity of ammonia to four species of marine amphipod. Marine Environmental Research, 38(1): 1-15, https://doi.org/10.1016/0141-1136(94)90042-6.

Lai K P, Li J W, Tse A C K, Cheung A, Wang S, Chan T F, Kong R Y C, Wu R S S. 2016. Transcriptomic responses of marine medaka's ovary to hypoxia. Aquatic Toxicology, 177: 476483, https://doi.org/10.1016/j.aquatox.2016.06.023. 
Lewis N I, Xu W B, Jericho S K, Kreuzer H J, Jericho M H, Cembella A D. 2006. Swimming speed of three species of Alexandrium (Dinophyceae) as determined by digital inline holography. Phycologia, 45(1): 61-70, https://doi. org/10.2216/04-59.1.

Li X D, Yan T, Lin J N, Yu R C, Zhou M J. 2017. Detrimental impacts of the dinoflagellate Karenia mikimotoi in Fujian coastal waters on typical marine organisms. Harmful Algae, 61: 1-12, https://doi.org/10.1016/j.hal.2016.11.011.

Li X L, Shi H M, Xia H Y, Zhou Y P, Qiu Y W. 2014. Seasonal hypoxia and its potential forming mechanisms in the Mirs Bay, the northern South China Sea. Continental Shelf Research, 80: 1-7, https://doi.org/10.1016/j.csr.2014.03. 003.

Li X X, Bianchi T S, Yang Z S, Osterman L E, Allison M A, DiMarco S F, Yang G P. 2011. Historical trends of hypoxia in Changjiang River estuary: applications of chemical biomarkers and microfossils. Journal of Marine Systems, 86(3-4): 57-68, https://doi.org/10.1016/j.jmarsys.2011.02. 003.

Liang Y B. 2012. Investigation and Evaluation of Red Tide in China Ocean. China Ocean Press, Beijing. (in Chinese)

Lu D D, Goebel J, Qi Y Z, Zou J Z, Han X T, Gao Y H, Li Y G. 2005. Morphological and genetic study of Prorocentrum donghaiense Lu from the East China Sea, and comparison with some related Prorocentrum species. Harmful Algae, 4(3): 493-505, https://doi.org/10.1016/j.hal.2004.08.015.

Lučić D, Hure M, Bobanović-Ćolić S, Njire J, Vidjak O, Onofri I, Gangai Zovko B, Batistić M. 2019. The effect of temperature change and oxygen reduction on zooplankton composition and vertical distribution in a semi-enclosed marine system. Marine Biology Research, 15(4-6): $325-$ 342, https://doi.org/10.1080/17451000.2019.1655161.

Luo L, Li S Y, Li H M. 2005. Characteristics of dissolved oxygen and its affecting factors in the Pearl River Estuary in summer. Acta Scientiarum Naturalium Universitatis Sunyatseni, 44(6): 118-122, https://doi.org/10.3321/j. issn:0529-6579.2005.06.031. (in Chinese with English abstract)

Marcus N H. 2001. Zooplankton: responses to and consequences of hypoxia. In: Rabalais N N, Turner R E eds. Coastal Hypoxia: Consequences for Living Resources and Ecosystems. American Geophysical Union, Washington, https://doi.org/10.1029/CE058p0049.

Micheli F. 1999. Eutrophication, fisheries, and consumerresource dynamics in marine pelagic ecosystems. Science, 285(5432): 1 396-1 398, https://doi.org/10.1126/science. 285.5432.1396.

Morrison J A, Gamble J C, Napier I R. 1991. Mass mortality of herring eggs associated with a sedimenting diatom bloom. ICES Journal of Marine Science, 48(2): 237-245, https:// doi.org/10.1093/icesjms/48.2.237.

O'Boyle S, McDermott G, Silke J, Cusack C. 2016. Potential impact of an exceptional bloom of Karenia mikimotoi on dissolved oxygen levels in waters off western Ireland. Harmful Algae, 53: 77-85, https://doi.org/10.1016/j. hal.2015.11.014.
Reddy-Lopata K, Auerswald L, Cook P. 2006. Ammonia toxicity and its effect on the growth of the South African abalone Haliotis midae Linnaeus. Aquaculture, 261(2): 678-687, https://doi.org/10.1016/j.aquaculture.2006.06. 020.

Reise K, van Beusekom J E E. 2008. Interactive effects of global and regional change on a coastal ecosystem. Helgoland Marine Research, 62(1): 85-91, https://doi. org/10.1007/s10152-007-0102-7.

Riedel B, Diaz R, Rosenberg R, Stachowitsch M. 2016. The Ecological Consequences of Marine Hypoxia: from Behavioural to Ecosystem Responses. Oxford University Press, Oxford. p.175-194.

Samuel C L, Yolanda H S N, Emilio L C S, Pedro C H, Felipe De Jesús A V, María Teresa S. 2019. Survival and respiration of green abalone (Haliotis fulgens) facing very short-term marine environmental extremes. Marine and Freshwater Behaviour and Physiology, 52(1): 1-15, https://doi.org/10.1080/10236244.2019.1607734.

Shi X Y, Wang X L, Lu R, Sun X. 2005. Distribution of dissolved oxygen and $\mathrm{pH}$ in frequent $\mathrm{HAB}$ area of the East China Sea in spring 2002. Oceanologia et Limnologia Sinica, 36(5): 404-412, https://doi.org/10.3321/j. issn:0029-814X.2005.05.003. (in Chinese with English abstract)

Shivarudrappa S K, Rakocinski C F, Briggs K B. 2019. Vertical distribution of macrobenthos in hypoxia-affected sediments of the Northern Gulf of Mexico: applying functional metrics. Estuaries and Coasts, 42(1): 250-263, https://doi.org/10.1007/s12237-018-0446-z.

Shivarudrappa S, Briggs K, Hartmann V. 2009. Benthic community response to hypoxia: baseline data. In: Proceedings of OCEANS 2009. IEEE, Biloxi, USA. p.16, https://doi.org/10.23919/OCEANS.2009.5422233.

Small D P, Bennett R S, Bishop C D. 2014. The roles of oxygen and ammonia in the symbiotic relationship between the spotted salamander Ambystoma maculatum and the green alga Oophila amblystomatis during embryonic development. Symbiosis, 64(1): 1-10, https://doi.org/10. 1007/s13199-014-0297-8.

Stalder L C, Marcus N H. 1997. Zooplankton responses to hypoxia: behavioral patterns and survival of three species of calanoid copepods. Marine Biology, 127(4): 599-607, https://doi.org/10.1007/s002270050050.

Trainer V L, Pitcher G C, Reguera B, Smayda T J. 2010. The distribution and impacts of harmful algal bloom species in eastern boundary upwelling systems. Progress in Oceanography, 85(1-2): 33-52, https://doi.org/10.1016/j. pocean.2010.02.003.

Vaquer-Sunyer R, Duarte C M. 2008. Thresholds of hypoxia for marine biodiversity. Proceedings of the National Academy of Sciences of the United States of America, 105(40): 15 452-15 457, https://doi.org/10.1073/pnas. 0803833105 .

Wang B D, Wei Q S, Chen J F, Xie L P. 2012a. Annual cycle of hypoxia off the Changjiang (Yangtze River) Estuary. Marine Environmental Research, 77: 1-5, https://doi. 
$\operatorname{org} / 10.1016 /$ j.marenvres.2011.12.007.

Wang C, Yu R C, Zhou M J. 2012b. Effects of the decomposing green macroalga Ulva (Enteromorpha) prolifera on the growth of four red-tide species. Harmful Algae, 16: 1219, https://doi.org/10.1016/j.hal.2011.12.007.

Wang W Q, Jiang L X, Yang N, Li J, Wang R J. 2007. The effect of ammonia-N on immune activity of Ruditapes philippinarum. Marine Science, 31(1): 23-27, https://doi. org/10.3969/j.issn.1000-3096.2007.01.005. (in Chinese with English abstract)

Wei H, He Y C, Li Q J, Liu Z Y, Wang H T. 2007. Summer hypoxia adjacent to the Changjiang Estuary. Journal of Marine Systems, 67(3-4): 292-303, https://doi. org/10.1016/j.jmarsys.2006.04.014.

Yang L F, Chen L L, Li X J, Zhou Z Q, Liu B, Song B, Li B J, Li B Q. 2019. Effect of seasonal hypoxia on macrobenthic communities in the Muping Marine Ranch, Yantai, China. Biodiversity Science, 27(2): 200-210, https://doi.org/10. 17520/biods.2019012. (in Chinese with English abstract)

Yu R C, Lü S H, Liang Y B. 2018. Harmful algal blooms in the coastal waters of China. In: Glibert P M, Berdalet E, Burford M A, Pitcher G C, Zhou M J eds. Global Ecology and Oceanography of Harmful Algal Blooms. Springer,
Cham. p.309-316, https://doi.org/10.1007/978-3-31970069-4_15.

Zhang H, Li Y F, Tang C, Zou T, Yu J, Guo K. 2016. Spatial characteristics and formation mechanisms of bottom hypoxia zone in the Bohai Sea during summer. Chinese Science Bulletin, 61(14): 1 612-1 620, https://doi.org/10. 1360/N972015-00915.(in Chinese with English abstract)

Zhao H D, Kao S J, Zhai W D, Zang K P, Zheng N, Xu X M, Huo C, Wang J Y. 2017. Effects of stratification, organic matter remineralization and bathymetry on summertime oxygen distribution in the Bohai Sea, China. Continental Shelf Research, 134: 15-25, https://doi.org/10.1016/j. csr.2016.12.004.

Zheng J J, Gao S, Liu G M, Wang H, Zhu X M. 2016. Modeling the impact of river discharge and wind on the hypoxia off Yangtze Estuary. Natural Hazards and Earth System Sciences, 16(12): 2 559-2 576, https://doi.org/10.5194/ nhess-16-2559-2016.

Zhu L M, Gao N, Wang R F, Zhang L. 2018. Proteomic and metabolomic analysis of marine medaka (Oryzias melastigma) after acute ammonia exposure. Ecotoxicology, 27(3): 267-277, https://doi.org/10.1007/s10646-0171892-2. 